\title{
Spatial distribution of viruses, bacteria and chlorophyll in the northern South China Sea
}

\author{
Lei He $\mathrm{H}^{1,3,4,5}$, Kedong Yin ${ }^{1,2, *}$, Xiangcheng Yuan ${ }^{1,3}$, Dongmei $\mathrm{Li}^{1,3}$, Derong Zhang ${ }^{1,3}$, \\ Paul J. Harrison ${ }^{3}$ \\ ${ }^{1}$ Key Laboratory of Tropical Marine Environmental Dynamics, South China Sea Institute of Oceanology, \\ Chinese Academy of Sciences, Guangzhou 510301, PR China \\ ${ }^{2}$ Australian Rivers Institute, Griffith University (Nathan Campus), Brisbane, Queensland 4111, Australia \\ ${ }^{3}$ Atmospheric, Marine and Coastal Environment (AMCE) Program, Hong Kong University of Science and Technology, \\ Clear Water Bay, Kowloon, Hong Kong SAR \\ ${ }^{4}$ Graduate University of Chinese Academy of Sciences, 19A Yuquan Road, Shijingshan District, Beijing 100049, PR China \\ ${ }^{5}$ Present address: Institute of Oceanology, Chinese Academy of Sciences, Qingdao 266071, PR China
}

\begin{abstract}
The South China Sea is one of the largest marginal seas in the world. A cruise was conducted during September 2005 to investigate the spatial distribution of viral and bacterial abundance as well as nutrient and chlorophyll a ( $\mathrm{chl} \mathrm{a)} \mathrm{concentrations} \mathrm{in} \mathrm{the} \mathrm{northern} \mathrm{South} \mathrm{China}$ Sea (SCS). The northern SCS was divided into 3 regions: the estuarine coastal plume, continental shelf, and open ocean. Except for the estuarine coastal waters, the northern SCS is oligotrophic. The distribution of chl a and viral and bacterial abundances were closely related to the water mass since higher chl $a$ and viral and bacterial abundances occurred in the upwelling region and the cold eddy. Viral and bacterial abundances decreased from the estuarine waters to offshore waters. On average, viral abundance was significantly higher $(\mathrm{p}<0.05)$ in the estuarine coastal plume $(25.2 \pm 3.1 \times$ $\left.10^{6} \mathrm{ml}^{-1}\right)$, than on the continental shelf $\left(14.1 \pm 6.5 \times 10^{6} \mathrm{ml}^{-1}\right)$ or the open ocean $\left(11.7 \pm 5.3 \times 10^{6} \mathrm{ml}^{-1}\right)$. Bacterial abundance followed a similar spatial distribution, ranging from $4.6 \pm 1.1 \times 10^{6} \mathrm{ml}^{-1}$ in the estuary to $1.6 \pm 0.8 \times 10^{6} \mathrm{ml}^{-1}$ in the open ocean. Ratios of viral to bacterial abundance (VBR) increased from near-shore to the coast and open ocean $(5.6 \pm 0.7,6.1 \pm 2.2$ and $8.4 \pm 4.7$, respectively). This is due to the fact that viral abundance decreased slower than bacterial abundance from the estuarine plume to the open ocean. Viral abundance was more significantly correlated with bacterial abundance $(\mathrm{p}<0.0001)$ than with chl a concentration $(\mathrm{p}=0.001)$, suggesting that bacteria were the major host members for marine viruses in the oligotrophic northern SCS. The highest abundance of viruses highlighted the significant influence of the relatively nutrient- and organic-rich Pearl River outflow on the northern SCS and indicated that viruses also responded to anthropogenic inputs in marine ecosystems.
\end{abstract}

KEY WORDS: Marine viruses · Marine bacteria $\cdot$ Chlorophyll a South China Sea Pearl River estuary $\cdot$ Virus-to-bacterium ratio

\section{INTRODUCTION}

Viruses are the most abundant and dynamic components among the microorganisms in the surface waters of the world's oceans. They probably infect all organisms, undergo rapid decay and replenishment (Noble \& Fuhrman 1997), and influence many biogeochemical and ecological processes (Bratbak et al. 1992, Fuhrman
1999, Suttle 2005), including nutrient cycling (Wilhelm \& Suttle 1999), system respiration (Bratbak et al. 1990), particle size distribution and sinking rates (Fuhrman 1992), bacterial and algal biodiversity, and species distributions (Fuhrman 1997). Abundance of viruses or virus-like particles (VLPs) in aquatic ecosystems in oceans, polar seas, rivers, lakes, and salt marshes ranges from $10^{4}$ to $10^{8} \mathrm{VLPs} \mathrm{ml}^{-1}$ (Wommack \& Colwell 
2000), often exceeding bacterial abundance by an order of magnitude (Proctor et al. 1988, Bergh et al. 1989). Studies on the spatial distribution of viruses and their specific hosts have been conducted in estuaries, coastal waters, and open oceans, as well as in freshwater ecosystems (Paul et al. 1991, Boehme et al. 1993, Maranger \& Bird 1995, Noble \& Fuhrman 1998, Wommack \& Colwell 2000).

Viral abundance is associated with the trophic status of an ecosystem (Weinbauer et al. 1993), hence its variability is correlated with other biological variables such as phytoplankton (Maranger \& Bird 1995, Wommack \& Colwell 2000) and bacterial abundance (Paul et al. 1991, Weinbauer \& Suttle 1997, Alonso et al. 2001, Culley \& Welschmeyer 2002). For example, a transect from Tampa Bay, Florida, to an oceanic station in the Gulf of Mexico found viral abundance at nearshore surface to be 2 orders of magnitude greater than at offshore surface (Boehme et al. 1993). Therefore the trophic status has been proposed as a possible driving force that controls the spatial distribution of viruses along an onshore-to-offshore transect (Weinbauer et al. 1993). Eutrophic environments support a higher standing stock of bacteria and phytoplankton than oligotrophic systems, and thus eutrophication can directly stimulate viral development (Weinbauer et al. 1993, Maranger \& Bird 1995) by providing more hosts for viruses.

The South China Sea (SCS), which is located in the tropical-subtropical rim of the western North Pacific Ocean, is one of the largest marginal seas. It extends from the equator to $22^{\circ} \mathrm{N}$ (see Fig. 1) and has a surface area of about $3.5 \times 10^{6} \mathrm{~km}^{2}$. The SCS receives extensive runoff from several large rivers, such as the Mekong and Pearl Rivers. It has a wide continental shelf to the northwest and south (Chen et al. 2001, Liu et al. 2002), and a $4700 \mathrm{~m}$ deep basin (Shaw \& Chao 1994). Luzon Strait (sill depth $1900 \mathrm{~m}$ ) is the only major channel allowing effective water exchange with the western Pacific Ocean. The SCS is oligotrophic with high sea-surface temperature, low nutrients (Gong et al. 1992, Wu et al. 2003, Ning et al. 2005), low chlorophyll a (chl a) concentrations (Liu et al. 2002, Ning et al. 2005), and low primary productivity (Liu et al. 2002, Ning et al. 2005). However, few data are available on the abundance of viruses and bacteria in the SCS.

In order to understand the ecological role of marine viruses, it is necessary to establish their spatial distribution, and to determine the abundance of other microbial loop components, mainly bacteria and phytoplankton. The objectives of the present study were to investigate the distribution of viral abundance in the northern SCS and the relationships between viral, bacterial, and phytoplankton abundances.

\section{MATERIALS AND METHODS}

Sampling stations. A cruise on board the RV 'Experiment No. 3' was conducted in the northern SCS during September 2005. On the basis of bathymetric features, the northern SCS was divided into 3 distinct regions: the estuarine coastal plume, the continental shelf $(<200 \mathrm{~m}$ deep), and the open ocean. The estuarine coastal plume is the most eutrophic coastal region of the northern SCS, due to the influence of land runoff, particularly the Pearl River outflow. In contrast, the open ocean is an oligotrophic region with a depth between 200 and $4000 \mathrm{~m}$. The continental shelf is a transitional region with a depth between 35 and $200 \mathrm{~m}$. The cruise included 5 transects running perpendicular to the coastline, covering stations from the near-shore and continental shelf to the deep ocean. Samples were collected from 37 stations (Fig. 1). The E1 transect included Stns E001, E101, E103, E105, E107, and E407 and was used to represent a gradient of measured parameters from the estuary and continental shelf to the open ocean.

Sampling and measurements. A Sea-Bird SBE CTD was used to measure salinity and temperature in the water column. Water samples were collected with Niskin bottles from the surface to the bottom. A YSI
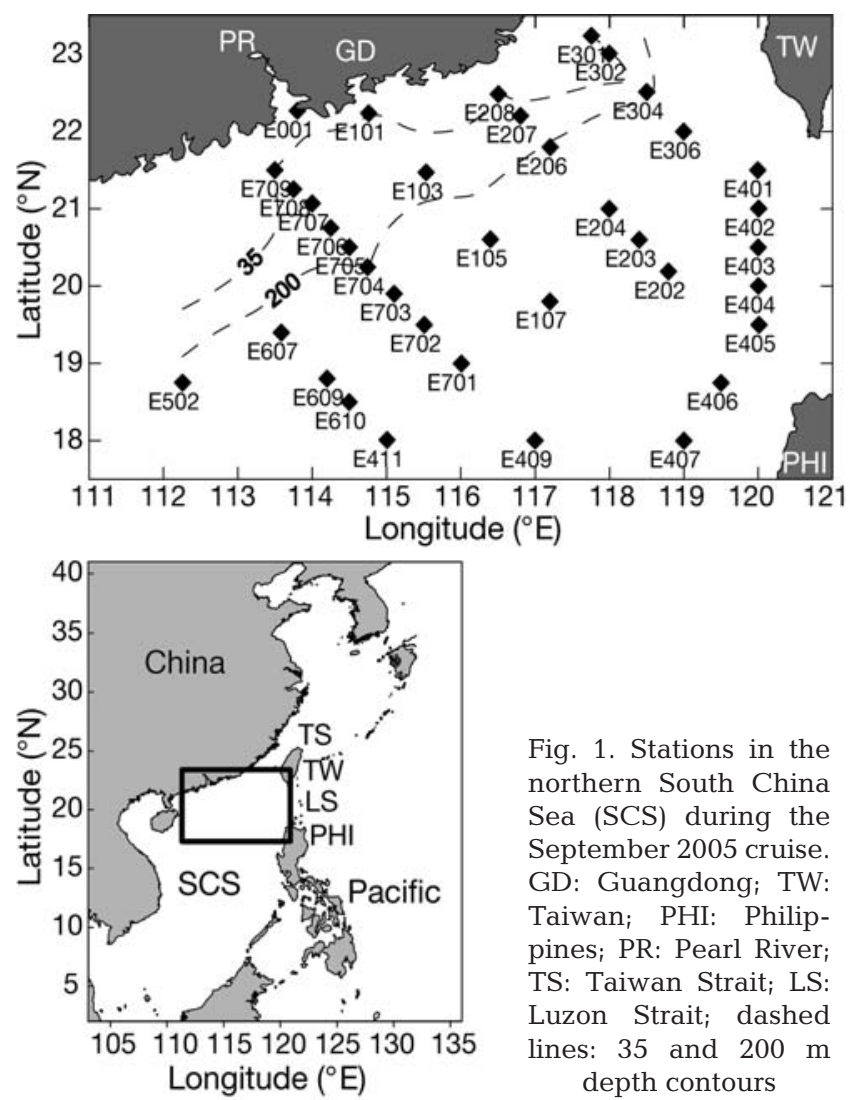

Fig. 1. Stations in the northern South China Sea (SCS) during the September 2005 cruise. GD: Guangdong; TW: Taiwan; PHI: Philippines; PR: Pearl River; TS: Taiwan Strait; LS: Luzon Strait; dashed lines: 35 and $200 \mathrm{~m}$ depth contours 
6600 calibrated with standard chl a concentrations was used to measure chl a concentration in the water column. Analyses of dissolved nutrients (nitrate = nitrate + nitrite, orthophosphate and silicate) were performed with seawater samples that were prefiltered through Whatman GF/F filters (pore size, $0.7 \mu \mathrm{m}$ ) by an auto-analyzer (SKALAR San ${ }^{++}$Plus Analyzer), using Joint Global Ocean Flux Study (JGOFS) protocols (Knap et al. 1996).

Both heterotrophic bacteria and viruses were counted on the same slide after staining a sample with SYBR Green I, according to Noble \& Fuhrman (1998). The SYBR Green I staining procedure was chosen as it has been shown to provide accurate measurements of viral abundance in water samples when viral abundance is relatively low $\left(<10^{8} \mathrm{ml}^{-1}\right)$ (Bettarel et al. 2000). Cyanobacteria were not counted. Samples for bacterial and viral abundance were transferred to $2 \mathrm{ml}$ centrifuge tubes, immediately fixed with glutaraldehyde (final concentration $0.5 \%$ ) and stored in darkness for $15 \mathrm{~min}$. After the $15 \mathrm{~min}$ fixation, $0.8 \mathrm{ml}$ samples were filtered onto $0.02 \mu \mathrm{m}$ Anodisc filters (Whatman) with a vacuum pressure of approximately $20 \mathrm{kPa}$. The filters were placed on a drop of SYBR Green I solution (final concentration $0.25 \%$ ) and stained for 15 min in darkness. The slides with the fixed filters were completed in about $30 \mathrm{~min}$ and stored at $-20^{\circ} \mathrm{C}$. The enumeration of bacteria and viruses was made within $4 \mathrm{wk}$. Immersion oil (type A, Nikon) was added to the fixed filter on the slide, and bacteria and viruses were counted at 1000× magnification under UV excitation using an OLYMPUS BX41 microscope with a $100 \mathrm{~W}$ mercury lamp for epifluorescence illumination. At least 200 bacteria and viruses in each field were counted in at least 10 fields.

ANOVAs and standard multiple regressions were performed using SPSS software. All means are \pm SD, unless stated otherwise. The results are presented as contour plots obtained with the SURFER program (Golden Software).

\section{RESULTS}

\section{Salinity and temperature}

The distribution of salinity and temperature in the northern SCS indicated that there were 5 water masses in the northern SCS (Fig. 2). The Pearl River estuarine coastal plume with lower salinity was evident near the Pearl River estuary, and to the northeast, a cold water mass was located near Taiwan Strait. Seawater of lower temperature and salinity invaded Taiwan Strait in the northeastern part of the SCS due to the typhoon 'Talim', which occurred $8 \mathrm{~d}$ before the cruise (see www. remss.com/cyclone/cyclone.html?year=2005\&storm= talim). To the southwest, there was a colder water mass with high salinity and to the southeast a warmer water mass, but salinity in the former was higher than in the latter. There was a warmer water mass with high salinity between Taiwan and Philippines, which was probably the surface water of the Kuroshio Current from Luzon Strait intruding into the SCS and flowing westward along the continental margin of China (Shaw 1991). Temperature increased southward from the estuarine coastal plume to the open ocean due to the decreasing latitude. The temperature range was relatively small, with a difference of only $1^{\circ} \mathrm{C}$ in the northern SCS, and was on average $28.5 \pm 0.7^{\circ} \mathrm{C}$ in the estuarine coastal plume, $28.7 \pm 0.7^{\circ} \mathrm{C}$ on the continental shelf, and $29.2 \pm 0.4^{\circ} \mathrm{C}$ in the open ocean. Salinity also increased southward from the estuarine coastal plume to the open ocean (Fig. 2). Salinity was on average 27.8 \pm 7.1 in the estuarine coastal plume, $32.9 \pm 1.3$ on the continental shelf, and $33.5 \pm 0.8$ in the open ocean.

\section{Nutrients and chl a}

The distribution of nutrients was generally in agreement with the hydrographic patterns as described above, and nutrients decreased southward from the

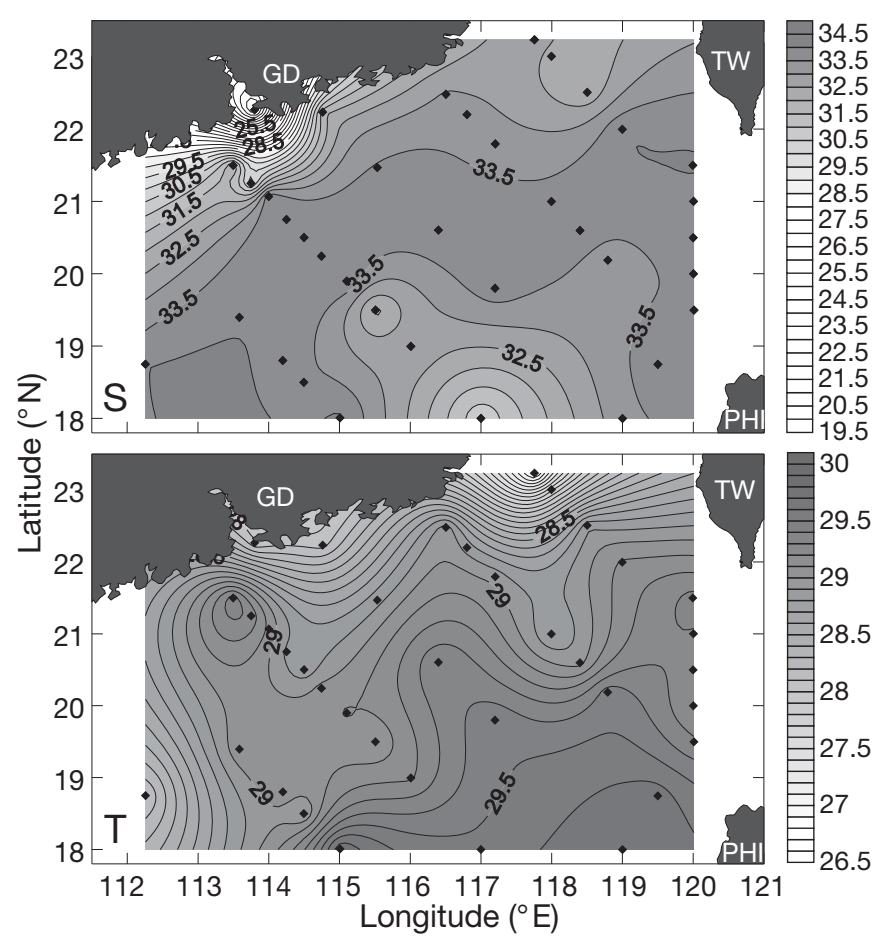

Fig. 2. Horizontal distribution of salinity (S) and temperature (T) at the surface in the northern South China Sea during September 2005. : sampled stations. See Fig. 1 for abbreviations 
Table 1. Mean $( \pm \mathrm{SD})$ nutrient values $\left(\mu \mathrm{mol}^{-1}\right)$ at surface of all stations in the northern South China Sea during September 2007

\begin{tabular}{|lccc|}
\hline & $\mathrm{NO}_{3}$ & $\mathrm{SiO}_{4}$ & $\mathrm{PO}_{4}$ \\
\hline Estuarine coastal plume & $11.4 \pm 17.4$ & $24.4 \pm 35.4$ & $0.7 \pm 0.7$ \\
Continental shelf & $1.8 \pm 1.4$ & $1.1 \pm 0.7$ & $0.3 \pm 0.2$ \\
Open ocean & $1.3 \pm 0.8$ & $1.1 \pm 0.7$ & $0.2 \pm 0.1$ \\
\hline
\end{tabular}

Pearl River estuarine coastal plume to the open ocean (Table 1, Fig. 3). There was a 10× decrease in nitrate and silicate and a $3 \times$ decrease in phosphate in the transect from the estuarine coastal plume to the open ocean (Table 1).

Chl a concentrations decreased seaward from the estuarine coastal plume to the open ocean. Average values were $3.4 \pm 0.6 \mu \mathrm{g} \mathrm{l}^{-1}$ in the estuarine coastal

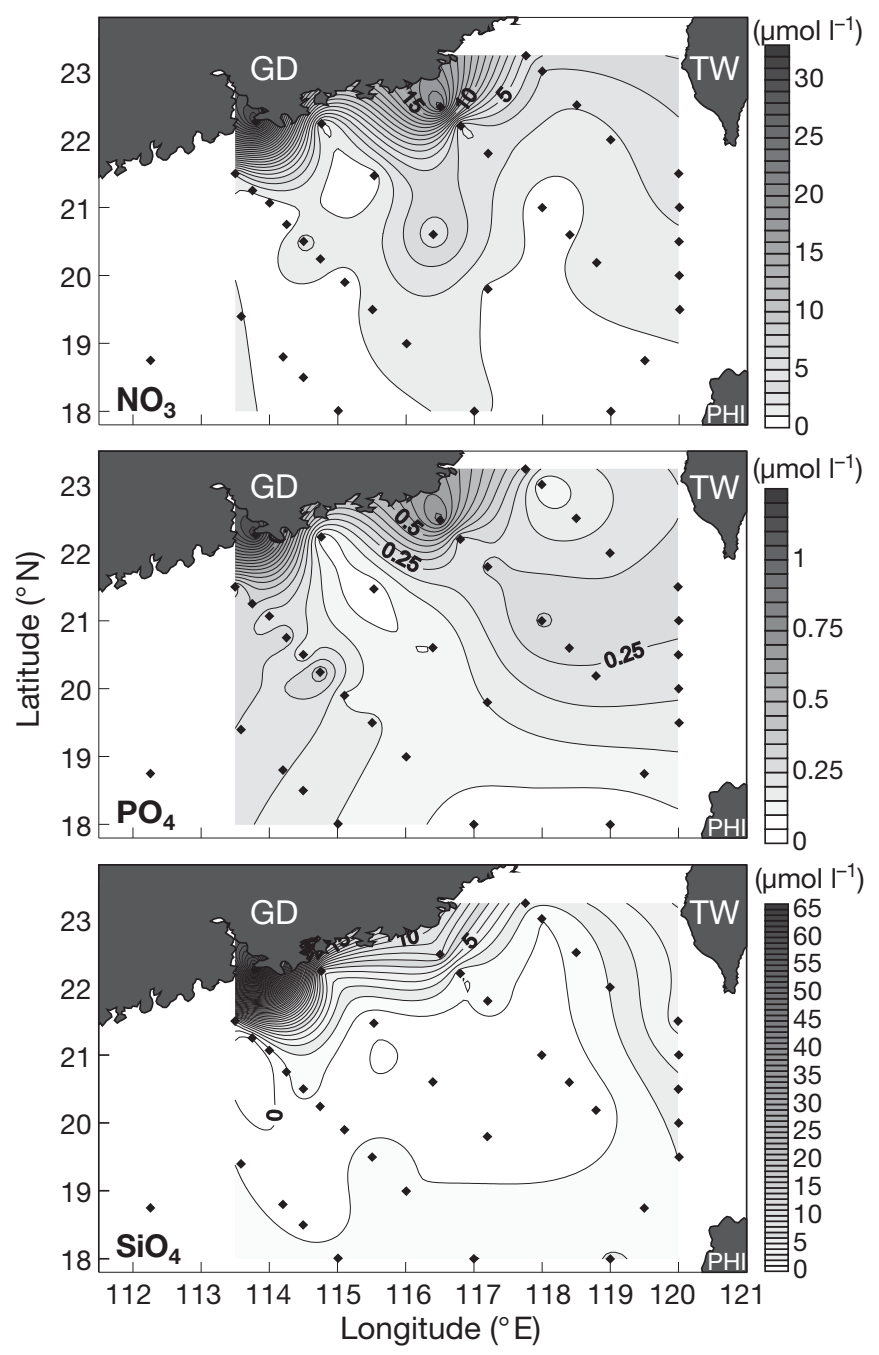

Fig. 3. Horizontal distribution of nutrient concentrations at the surface in the northern South China Sea during September 2005. : sampled stations. See Fig. 1 for abbreviations plume, $0.8 \pm 0.4 \mu \mathrm{g} \mathrm{l}^{-1}$ on the continental shelf, and $0.7 \pm 0.3 \mu \mathrm{g} \mathrm{l}^{-1}$ in the open ocean (Fig. 4). The highest values were obtained in the eutrophic Pearl River estuarine coastal plume and in Taiwan Strait due to the vertical mixing caused by the typhoon. Relatively low values were observed in the warmer water mass with higher salinity in the open ocean.

\section{Abundance of viruses and bacteria in the surface water}

Bacterial abundance displayed marked spatial variability and was about 3 times higher in the estuarine coastal plume than in the open ocean. The average surface bacterial abundance was $4.6 \pm 1.1 \times 10^{6} \mathrm{ml}^{-1}$ in the estuarine coastal plume, $2.7 \pm 1.6 \times 10^{6} \mathrm{ml}^{-1}$ on the continental shelf, and $1.6 \pm 0.8 \times 10^{6} \mathrm{ml}^{-1}$ in the open ocean (Fig. 4). The bacterial distribution was similar to that of chl a with a distinct estuarine influence (Fig. 4). The highest values were observed in the eutrophic Pearl River estuarine coastal plume and in Taiwan Strait due to the vertical mixing caused by the previous typhoon. Relatively high values were observed in the warmer water mass with lower salinity to the southeast

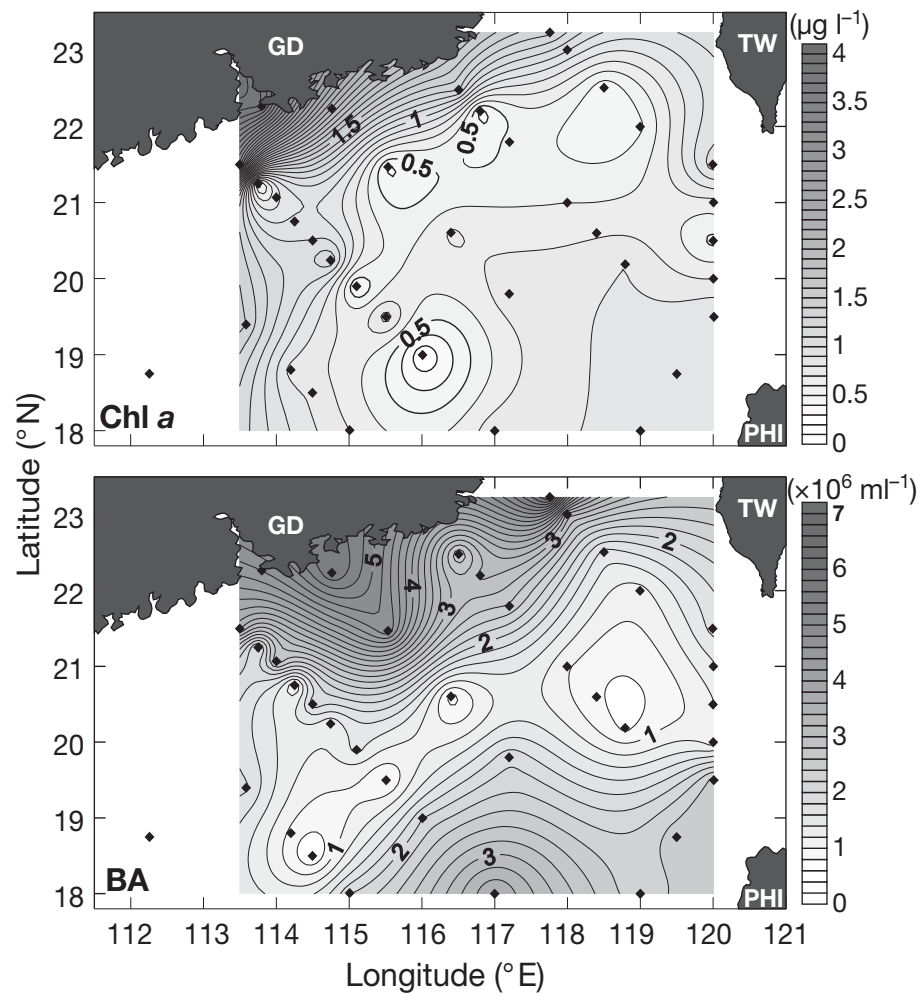

Fig. 4. Horizontal distribution of $\mathrm{chl} a$ and bacterial abundance (BA) at the surface in the northern South China Sea during September 2005. \$: sampled stations. See Fig. 1 for other abbreviations 
in the open ocean. In between the high coastal and intermediate open ocean values, there was a zone with low bacterial abundance beyond the $200 \mathrm{~m}$ contour and continental slope (Fig. 4).

The average viral abundance was $25.2 \pm 3.1 \times$ $10^{6} \mathrm{ml}^{-1}$ in the surface of the estuarine coastal plume, significantly different from $14.1 \pm 6.5 \times 10^{6} \mathrm{ml}^{-1}$ on the continental shelf, and $11.7 \pm 5.3 \times 10^{6} \mathrm{ml}^{-1}$ in the open ocean (Fig. 5). The highest abundance of viruses and bacteria occurred at Stn E101 near the eutrophic Pearl River estuary, although the chl a concentration was not the highest at this station. The second highest viral and bacterial abundance appeared at Stn E001 in the estuary, where the chl a concentration was the highest. The next highest viral and bacterial abundance was observed at Stn E301 due to the influence of the invasion of Taiwan Strait water after the typhoon.

The virus to bacteria abundance ratio (VBR) was used to examine the relationship between the abundance of viral and bacterial populations. The mean VBR was $5.6 \pm 0.7$ in the estuarine coastal plume, $6.1 \pm$ 2.2 on the continental shelf, and $8.4 \pm 4.7$ in the open ocean; these values were not statistically different from each other. The highest VBR values occurred in the open ocean of the northern SCS region (Fig. 5).

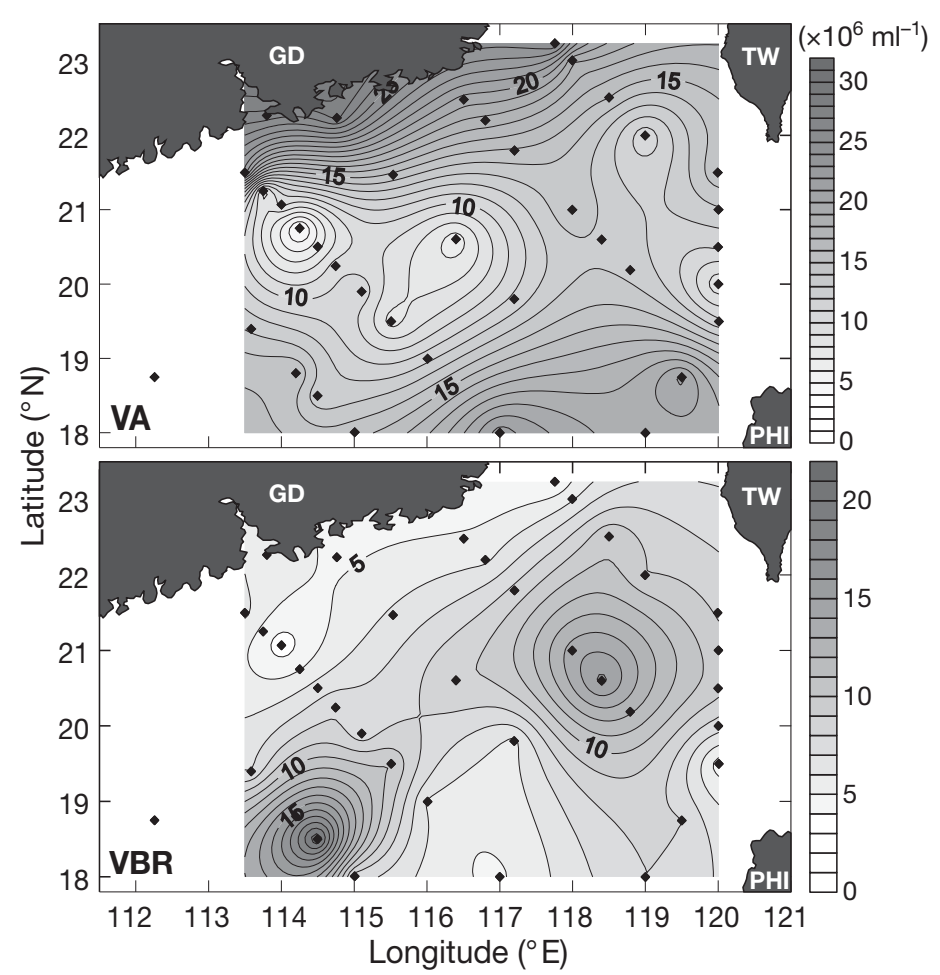

Fig. 5. Horizontal distribution of viral abundance (VA) and virus to bacteria ratio (VBR) at the surface in the northern South China Sea during September 2005. \&: sampled stations. See Fig. 1 for other abbreviations

\section{Vertical distribution}

The vertical distribution of salinity and temperature along the E1 transect showed that the vertical gradient in salinity was strong in the estuarine coastal plume, but was relatively small, with only a salinity difference of 1, in waters deeper than $100 \mathrm{~m}$ (Fig. 6). However, the temperature gradient was very large, being $30^{\circ} \mathrm{C}$ at the surface and decreasing to $16^{\circ} \mathrm{C}$ at $200 \mathrm{~m}$ at all oceanic stations.

Vertical gradients of chl a concentration, bacterial abundance, and viral abundance were larger in shallow waters than in deep waters along the E1 transect (Figs. 7 \& 8). Chl a concentration was highest between 50 and $75 \mathrm{~m}$. Chl a concentration and bacterial and viral abundances were lower throughout the entire water column at E105 than at other stations.

\section{DISCUSSION}

\section{Water masses and biomass}

Physical processes are important in influencing the spatial distribution of chl $a$ and bacterial and viral abundances. The northern SCS exhibits strong hori-

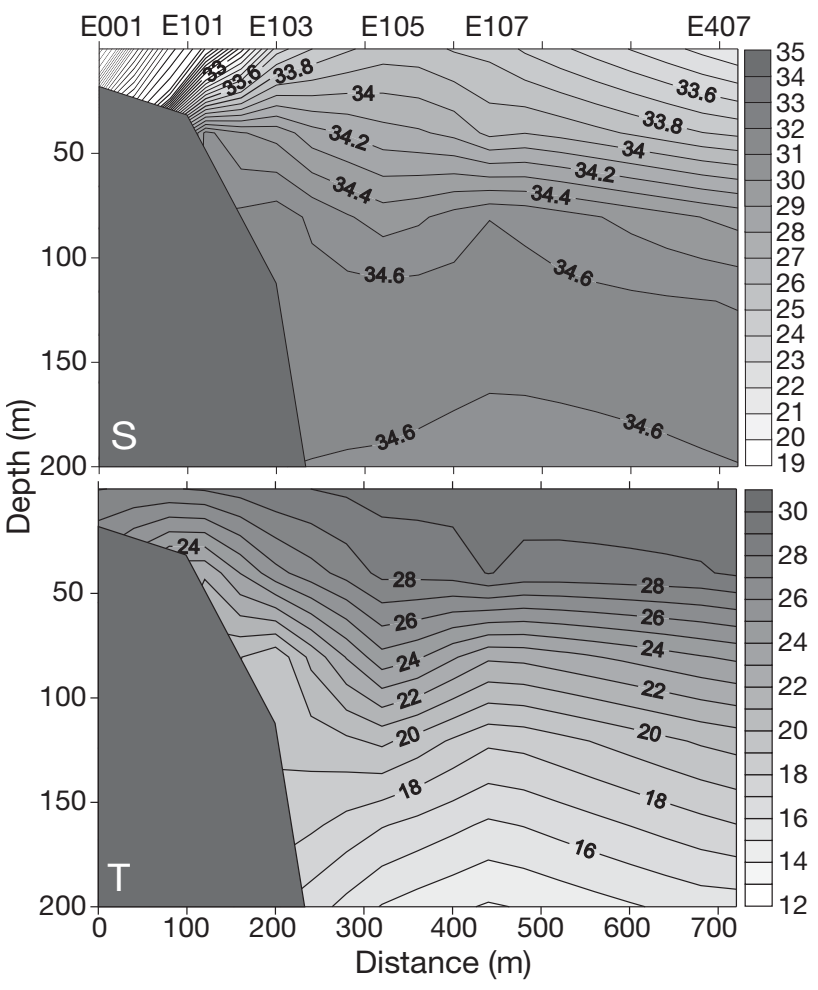

Fig. 6. Vertical distribution of salinity (S) and temperature (T) along the E1 transect (Stns E001, E101, E103, E105, E107 and E407) in the northern South China Sea during September 2005 


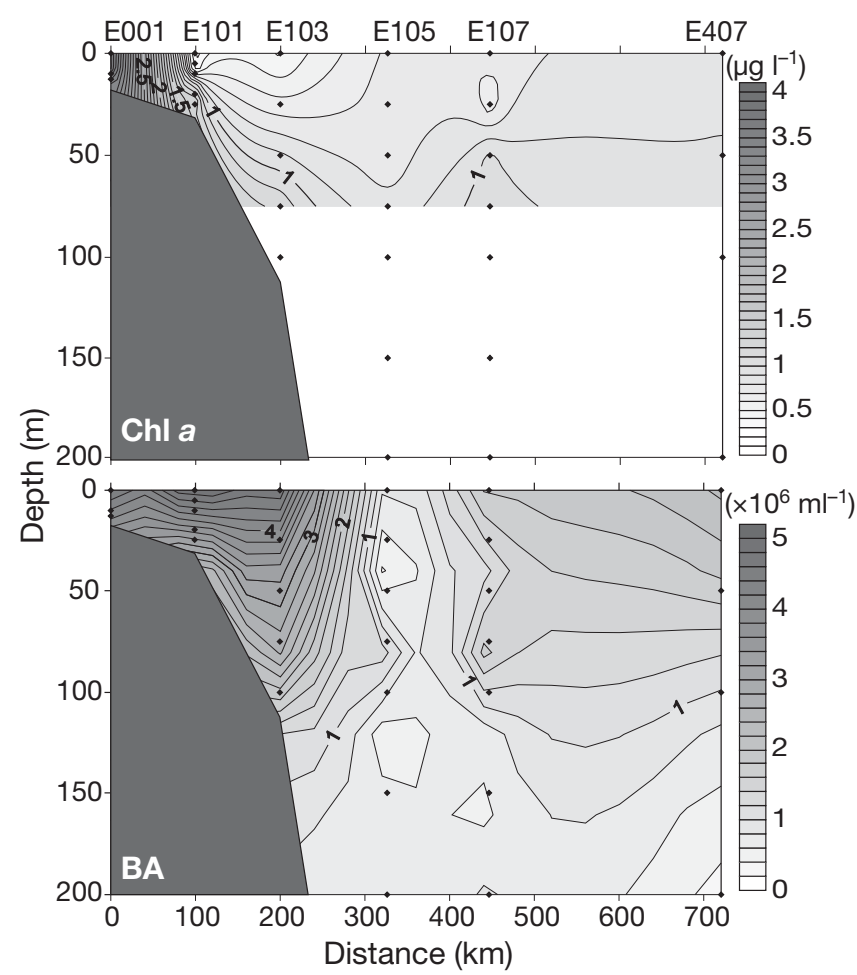

Fig. 7. Vertical distribution of chl a and bacterial abundance (BA) along the E1 transect in the northern South China Sea during September 2005. : sampled stations (see top of figure for station codes)

zontal physical gradients from near-shore to offshore primarily due to land runoff and the Pearl River outflow. The East Asia monsoon winds are the major physical drivers of the movement of water masses in the northern SCS. When the northeastern monsoon prevails during winter, saline water from the western Pacific Ocean flows through Luzon Strait and influences the water properties of the basin (Wyrtki 1961, Shaw 1991, Gong et al. 1992, Chu et al. 1997), as revealed by the distribution of salinity and temperature (Fig. 2). When the southwestern monsoon prevails during summer, the water properties of the basin are strongly influenced by waters from the southern part of the SCS and summer upwelling (Fan 1984). During the cruise in September 2005, low salinity waters from the Pearl River outflow occupied the coastal waters beyond the Pearl River Estuary (Fig. 2), resulting in high nutrients (Fig. 3). During September, monsoonal winds often shift between the southwest and northeast; as a result, there were high salinity waters near Taiwan Strait due to the Kuroshio Current invasion near Luzon Strait, and high salinity waters in the southwest part of the northern SCS that came from the south (Fig. 2) where nutrients were low (Fig. 3). Consequently, the low salinity water mass with higher nutrient concentrations resulted in higher chl a concentra-

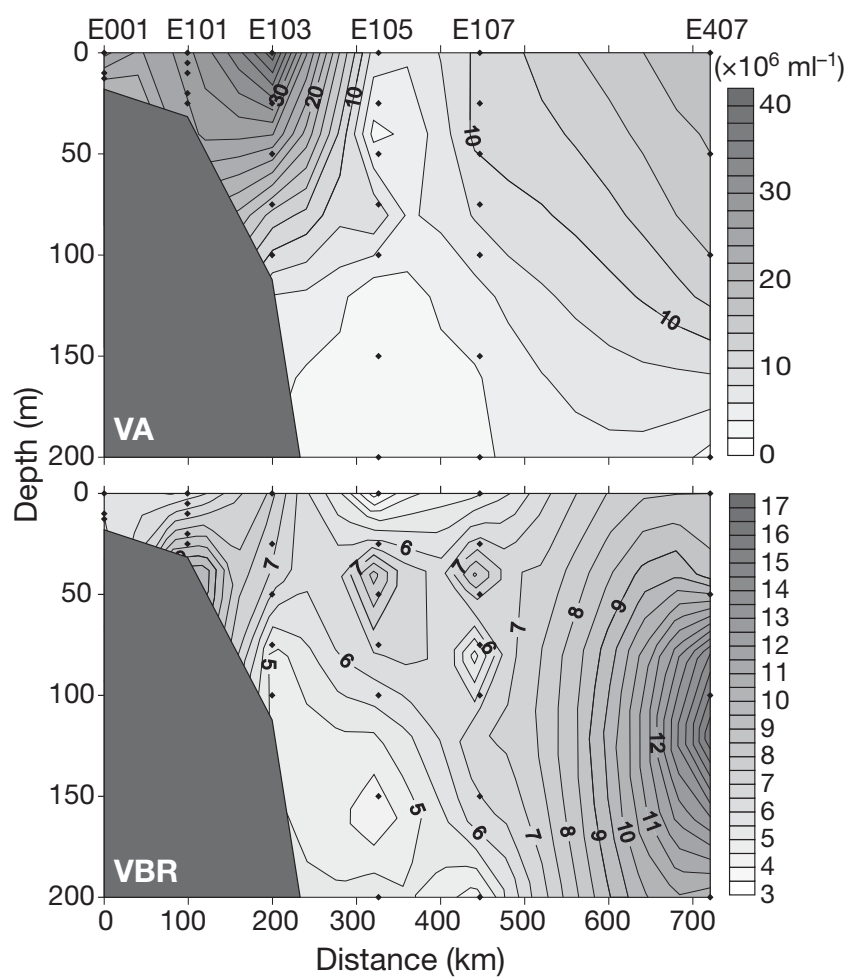

Fig. 8. Vertical distribution of viral abundance (VA) and virus to bacteria ratios (VBR) along the E1 transect in the northern South China Sea during September 2005. (see top of figure for station codes)

tions, bacterial abundance, and viral abundance, similar to coastal waters; higher salinity waters had lower chl $a$ and lower abundances of bacteria and viruses (Figs. 4 \& 5).

Chl a, bacterial abundance, and viral abundance appeared to be related to eddies. Cyclonic and anticyclonic eddies were found to be mesoscale features in the SCS (Hwang \& Chen 2000, He et al. 2002, Wang et al. 2003). Upwelled cold and saline water was visible between E101 and E103 and downwelling was present at E105, as shown in the vertical contours of salinity and temperature along the Pearl River estuarine outflow (Fig. 6). Additional evidence of upwelling and downwelling processes was the low dissolved oxygen water that appeared at $50 \mathrm{~m}$ at Stns E101 to E103 associated with upwelled colder water, whereas high dissolved oxygen water in the surface was observed down to $30 \mathrm{~m}$ at Stn E105 (L. He unpubl. data) where the temperature was $28^{\circ} \mathrm{C}$ (Fig. 6). As a result, higher chl a concentrations and bacterial and viral abundance occurred at Stns E101 and E103, but lower bacterial abundance was found in the downwelled water at Stn E105 (Figs. 7 \& 8).

Biological processes are often coupled with physical processes. The supply of nutrients is usually associated with waters of low salinity or cold temperatures 
relative to the surrounding waters. The maximum Pearl River discharge occurs in July (Yin 2003), and the extent of the estuarine coastal plume should be maximal in the northern SCS during August and early September, since freshwater outflow from the Pearl River spreads and mixes over the northern SCS before it is advected out of the SCS. As a result, estuarine nutrients will be utilized and result in higher chl $a$ in the low salinity waters. This agrees with observations of higher chl $a$ in the SCS associated with the movement of the estuarine coastal plume (Yin et al. 2000). The highest viral and bacterial abundances were observed in the estuarine-influenced waters. Cyclonic eddies are usually coupled with upwelling, which brings colder waters and higher nutrients to the surface, as observed by Ning et al. (2004). In contrast, anti-cyclonic eddies are coupled with downwelling, which results in warmer waters and less nutrients (Ning et al. 2004). Our observations agreed with those of previous studies; higher chl a concentrations occurred in colder waters with higher salinity in the southwest, and lower values occurred in warmer waters with lower salinity to the west of the Philippines and south of Luzon Strait. Similarly, higher abundances of bacteria and viruses occurred in waters with higher chl $a$, although the correlation was not significant. In contrast, low values of bacterial and viral abundance occurred in the waters influenced by the Kuroshio Current to the west of Luzon Strait and downwelling-induced warmer waters at Stn E105.

\section{Geographic comparisons}

The highest viral abundance occurred in the Pearl River estuarine plume, which is consistent with observations in other estuarine regions (Wommack \& Colwell 2000). While methods for counting viruses vary, comparisons with other areas showed that viral abundance ranged from 14 to $208 \times 10^{6} \mathrm{ml}^{-1}$ in the fall in the Charente Estuary, France (Auguet et al. 2005), 17.5 to $50.4 \times 10^{6} \mathrm{ml}^{-1}$ in August in the Gulf of Bothnia, Sweden (Cochlan et al. 1993), and 4.6 to $34 \times 10^{6} \mathrm{ml}^{-1}$ in Tampa Bay, Florida, USA (Paul et al. 1991, Boehme et al. 1993, Jiang \& Paul 1994, 1995, Cochran \& Paul 1998). The observations of high viral abundance in estuarine environments may be the result of the induction of prophages from anthropogenic inputs (Cochran \& Paul 1998).

Viral abundance ranged from 1.7 to $21.6 \times 10^{6} \mathrm{ml}^{-1}$ with a mean $( \pm \mathrm{SD})$ of $11.6 \pm 5.3 \times 10^{6} \mathrm{ml}^{-1}$, and was the lowest in the open SCS during September 2005. The range overlaps with the viral abundance reported for other enclosed seas, e.g. 0.056 to $29.6 \times 10^{6} \mathrm{ml}^{-1}$ in the northwestern Mediterranean Sea in July 1998 (Wein- bauer et al. 2003). The distribution in viral abundance from the coastal continental shelf to the open sea in the present study was very similar to that along a transect from the coastal waters of Monterey Bay, California to the open Pacific Ocean near Hawaii, with viral abundances ranging from 1.5 to $15 \times 10^{6} \mathrm{ml}^{-1}$ during September 1998 (Culley \& Welschmeyer 2002).

Viral abundance $\left(3.5\right.$ to $25.1 \times 10^{6} \mathrm{ml}^{-1}$, mean of $14.1 \pm 6.5 \times 10^{6} \mathrm{ml}^{-1}$ ) on the continental shelf also agreed with that from the upper layer of Japanese coastal waters (Hara et al. 1991), and in the coastal waters of Santa Monica and San Diego in Southern California (Cochlan et al. 1993). Viral abundance values on the continental shelf lie between that of the estuarine coastal plume and the open ocean because the continental shelf is a transitional region in the nutritional status and eutrophic conditions.

The VBR values for the present study are comparable with those reported by Corinaldesi et al. (2003) for the Adriatic Sea (ranging from 0.3 to 49.2), and by Hara et al. (1991) for Japanese coastal and offshore waters (2.3 to 18), slightly lower than those reported by Wommack et al. (1992) for Chesapeake Bay (12.6 to 25.6), and slightly higher than those reported by Jiang \& Paul (1994) for Tampa Bay (0.9 to 9.1).

These comparisons demonstrate that viral abundance varied widely among different oceans and between different areas in the same region, but there appeared to be a common pattern: the highest viral abundance occurred in near-shore waters, and the lowest abundance in offshore waters. The distribution of viruses is subject to various governing processes, such as physical processes and variation in phytoplankton biomass and bacterial abundance.

\section{Correlation between viral abundance and other factors}

The spatial distribution of viruses has been shown to be related to water masses in the northern SCS, as viruses were negatively correlated with salinity ( $\mathrm{r}=$ $-0.4458, \mathrm{n}=32, \mathrm{p}=0.0106)$ and temperature $(\mathrm{r}=$ $-0.4588, \mathrm{n}=32 \mathrm{p}=0.0083)$. Although viruses are plankton particles subjected to physical processes, the production and decay of viruses are determined more by factors which affect the productivity and density of host populations in a water mass. Therefore, the correlation between water mass properties and viruses found in the present study ultimately results from the variability in abundance of viral host populations such as phytoplankton and bacteria in the water mass. In the present study, there was a significant, positive correlation between viral abundance and chl a concentration. A positive correlation between chl a concentra- 
tion and viral abundance has also been shown in Tampa Bay (Boehme et al. 1993, Jiang \& Paul 1994). In some areas, there was a stronger correlation between viral abundance and chlorophyll $a$ than with bacterial abundance (Boehme et al. 1993, Jiang \& Paul 1994), and other studies have shown that chl a was a slightly better predictor of viral abundance than bacterial abundance (Maranger \& Bird 1995, Wommack \& Colwell 2000). One possible explanation for these observations is that viral abundance results from enhanced phytoplankton biomass and possibly an increase in viruses infecting the phytoplankton. Conversely, many other studies that have examined changes in bacterial and viral abundance, and have reported a significant correlation between the two (Cochlan et al. 1993, Weinbauer et al. 1993). In most marine environments, bacterial abundance is thought to better predict viral abundance, but this can be site-specific or seasonally influenced.

In the northern SCS, viral abundance was more significantly correlated with bacterial abundance $(\mathrm{r}=$ 0.8529, $\mathrm{p}<0.0001, \mathrm{n}=29$ ) than with chl a concentration $(\mathrm{r}=0.5883, \mathrm{p}=0.0010, \mathrm{n}=28)$. This suggests that bacteria were the main host organisms for marine viruses and, as a result, the variability in bacterial abundance was the main factor governing the viral abundance in the northern SCS. Several studies in other regions have also reported a significant correlation between bacterial and viral abundance in different marine environments (Paul et al. 1991, 1993, Boehme et al. 1993, Cochlan et al. 1993, Weinbauer et al. 1993, GuixaBoixareu et al. 1996, Weinbauer \& Suttle 1997, Alonso et al. 2001, Culley \& Welschmeyer 2002).

Studies of changes in VBR have revealed a clear association between VBR and bacterial abundance. The VBR value was significantly negatively correlated with bacterial abundance $(\mathrm{r}=-0.5683, \mathrm{p}=0.0011, \mathrm{n}=$ 30 ) in the northern SCS. Higher VBR values were recorded at times of relatively low bacterial abundance and vice versa, possibly due to an increase in cell abundance resulting in more infections, or a decreased residence time for the viruses. Similar results have also been reported in other regions (Jiang \& Paul 1994, Maranger \& Bird 1995, Tuomi et al. 1995). However, a positive relationship between VBR and bacterial numbers was noted in both oligotrophic water samples collected in the North Pacific (Hara et al. 1996) and eutrophic water samples collected from the northern Adriatic Sea (Weinbauer et al. 1995). Hara et al. (1996) suggested that higher VBR values coincided with larger numbers of small bacteria, and increased numbers of viruses may act as a positive selective pressure for reduced cell volume. This suggestion is also supported by the colloidal aggregation theory, which predicts that a smaller bacterium would encounter fewer phages through Brownian motion (Hara et al. 1996, Wommack \& Colwell 2000).

In summary, the large-scale spatial distribution of viruses in the northern SCS showed that viral abundance was low in this oligotrophic sea, and comparable to other oligotrophic areas. In the Pearl River estuarine coastal-influenced areas, viral abundance was the highest. On the one hand, the distribution of viral abundance was subjected to physical processes such as the movement of oceanic water masses (Kuroshio Current, Taiwan Strait and south SCS current), some mesoscale eddy circulation, as well as upwelling or downwelling, which determined the nutrient regimes in the water masses. On the other hand, as water masses move, changes in viral abundance are subject to viral decay and the interactions with phytoplankton and bacteria. Therefore, in the present study the spatial distribution of viral abundance was correlated with phytoplankton biomass, but more significantly correlated with bacterial abundance.

In contrast to some other studies, observations in the present study demonstrate that viral abundance does follow nutrient-related phytoplankton and bacterial activity levels, and supports the view that viruses are an important player in various ocean ecosystems (Suttle 2005). The highest viral abundance also highlights the significant influence of the relatively nutrient- and organic-rich Pearl River outflow upon the northern SCS, and indicates that viruses respond to anthropogenic inputs in marine ecosystems.

Acknowledgements. This study was supported by the National Science Foundation of China (NSFC project nos. 40676074, 40490264 and 40676020), and Hong Kong RGC project no. HKUST6505/06M. Ship time was provided by the 'Open Cruises' Program offered by the South China Sea Institute of Oceanology. We thank the officers and crew of the RV 'Experiment No. 3' for assistance and cooperation, D. X. Wang for valuable comments, R. Y. Chen and H. B. Mao for providing the CTD data report, and the staff of the coastal marine lab of the Hong Kong University of Science and Technology for equipment support.

\section{LITERATURE CITED}

Alonso MC, Jimenez-Gomez F, Rodriguez J, Borrego JJ (2001) Distribution of virus-like particles in an oligotrophic marine environment (Alboran Sea, western Mediterranean). Microb Ecol 42:407-415

Auguet JC, Montanie H, Delmas D, Hartmann HJ, Huet V (2005) Dynamic of viroplankton abundance and its environmental control in the Charente Estuary (France). Microb Ecol 50:337-349

Bergh O, Borsheim KY, Bratbak G, Heldal M (1989) High abundance of viruses found in aquatic environments. Nature 340:467-468

Bettarel Y, Sime-Ngando T, Amblard C, Laveran H (2000) A comparison of methods for counting viruses in aquatic systems. Appl Environ Microbiol 66:2283-2289 
Boehme J, Frischer ME, Jiang SC, Kellogg CA and others (1993) Viruses, bacterioplankton, and phytoplankton in the southeastern Gulf of Mexico: distribution and contribution to oceanic DNA pools. Mar Ecol Prog Ser 97:1-10

Bratbak G, Heldal M, Norland S, Thingstad TF (1990) Viruses as partners in spring bloom microbial trophodynamics. Appl Environ Microbiol 56:1400-1405

Bratbak G, Heldal M, Thingstad TF, Riemann B, Haslund OH (1992) Incorporation of viruses into the budget of microbial C-transfer. A first approach. Mar Ecol Prog Ser 83: $273-280$

> Chen CTA, Wang SL, Wang BJ, Pai SC (2001) Nutrient budgets for the South China Sea basin. Mar Chem 75:281-300

> Chu PC, Lu S, Chen Y (1997) Temporal and spatial variabilities of the South China Sea surface temperature anomaly. J Geophys Res 102:20937-20955

Cochlan WP, Wikner J, Steward GF, Smith DC, Azam F (1993) Spatial distribution of viruses, bacteria, and chlorophyll $a$ in neritic, oceanic and estuarine environments. Mar Ecol Prog Ser 92:77-87

- Cochran PK, Paul JH (1998) Seasonal abundance of lysogenic bacteria in a subtropical estuary. Appl Environ Microbiol 64:2308-2312

Corinaldesi C, Crevatin E, Del Negro P, Marini M, Russo A, Fonda-Umani S, Danovaro R (2003) Large-scale spatial distribution of virioplankton in the Adriatic Sea: testing the trophic state control hypothesis. Appl Environ Microbiol 69:2664-2673

Culley AI, Welschmeyer NA (2002) The abundance, distribution, and correlation of viruses, phytoplankton, and prokaryotes along a Pacific Ocean transect. Limnol Oceanogr 47:1508-1513

Fan KL (1984) The branch of Kuroshio in the Taiwan Strait. In: Ichiye $\mathrm{T}$ (ed) Ocean hydrodynamics of the Japan and East China Sea. Elsevier, New York, p 77-82

Fuhrman JA (1992) Bacterioplankton roles in cycling of organic matter: the microbial food web. In: Falkowski PG, Woodhead AD (eds) Primary productivity and biogeochemical cycles in the sea. Plenum Press, New York, p 361-383

Fuhrman JA (1999) Marine viruses and their biogeochemical and ecological effects. Nature 399:541-548

Gong G, Liu KK, Liu C, Pai S (1992) The chemical hydrography of the South China Sea west of Luzon and a comparison with the west Philippine Sea. Terr Atmos Ocean Sci 3: $587-602$

Guixa-Boixareu N, Calderón-Paz JI, Heldal M, Bratbak G, Pedrós-Alió C (1996) Viral lysis and bacterivory as prokaryotic loss factors along a salinity gradient. Aquat Microb Ecol 11:215-227

Hara S, Terauchi K, Koike I (1991) Abundance of viruses in marine waters assessment by epifluorescence and transmission electron microscopy. Appl Environ Microbiol 57: 2731-2734

> Hara S, Koike I, Terauchi K, Kamiya H, Tanoue E (1996) Abundance of viruses in deep oceanic waters. Mar Ecol Prog Ser 145:269-277

He ZG, Wang DX, Hu J (2002) Features of eddy kinetic energy and variations of upper circulation in the South China Sea. Acta Oceanol Sin 21:305-314

Hwang C, Chen SA (2000) Circulations and eddies over the South China Sea derived from TOPEX/Poseidon altimetry. J Phys Oceanogr 105:23943-23965

> Jiang SC, Paul JH (1994) Seasonal and diel abundance of viruses and the occurrence of lysogeny/bacteriocinogeny in the marine environment. Mar Ecol Prog Ser 104: $163-172$
Jiang SC, Paul JH (1995) Viral contribution to dissolved DNA in the marine environment as determined by differential centrifugation and kingdom probing. Appl Environ Microbiol 61:317-325

Knap A, Michaels A, Close A, Ducklow H, Dickson A (1996) Protocols for the Joint Global Ocean Flux Study (JGOFS) Core Measurements. JGOFS Report no. 19. Reprint of the IOC Manuals and Guides no. 29, UNESCO, Paris

Liu KK, Chao SY, Shaw PT, Gong GC, Chen CC, Tang TY (2002) Monsoon-forced chlorophyll distribution and primary production in the South China Sea: observations and a numerical study. Deep-Sea Res I 49:1387-1412

Maranger R, Bird DF (1995) Viral abundance in aquatic systems: a comparison between marine and fresh waters. Mar Ecol Prog Ser 121:217-226

> Ning X, Chai F, Xue H, Cai Y, Liu C, Shi J (2004) Physical-biological oceanographic coupling influencing phytoplankton and primary production in the South China Sea. J Geophys Res 109, C10005, doi: 10.1029/ 2004JC002365

Ning X, Li WKW, Cai Y (2005) Standing stock and community structure of photosynthetic picoplankton in the northern South China Sea. Acta Oceanol Sin 24:57-76

Noble RT, Fuhrman JA (1997) Virus decay and its causes in coastal waters. Appl Environ Microbiol 63:77-83

Noble RT, Fuhrman JA (1998) Use of SYBR Green I for rapid epifluorescence counts of marine viruses and bacteria. Aquat Microb Ecol 14:113-118

Paul JH, Jiang SC, Rose JB (1991) Concentration of viruses and dissolved DNA from aquatic environments by vortex flow filtration. Appl Environ Microbiol 57:2197-2204

$>$ Paul JH, Rose JB, Jiang SC, Kellogg CA, Dickson L (1993) Distribution of viral abundance in the reef environment of Key Largo, Florida. Appl Environ Microbiol 59:718-724

Proctor LM, Fuhrman JA, Ledbetter MC (1988) Marine bacteriophages and bacterial mortality. EOS Trans Am Geophys Union 69:1111-1112

Shaw PT (1991) The seasonal variation of the intrusion of the Philippine Sea water into the South China Sea. J Geophys Res 96:821-827

Shaw PT, Chao SY (1994) Surface circulation in the South China Sea. Deep-Sea Res Part I 41:1663-1683

Suttle CA (2005) Viruses in the sea. Nature 437:356-361

Tuomi P, Fagerbakke KM, Bratbak G, Heldal M (1995) Nutritional enrichment of a microbial community: the effects on activity, elemental composition, community structure and virus production. FEMS Microbiol Ecol 16:123-134

> Wang GH, Su JL, Chu PC (2003) Mesoscale eddies in the South China Sea observed with altimeter data. Geophys Res Lett 30, 2121, doi: 10.1029/2003GL018532

Weinbauer MG, Suttle CA (1997) Comparison of epifluorescence and transmission electron microscopy for counting viruses in natural marine waters. Aquat Microb Ecol 13: 225-232

Weinbauer MG, Fuks D, Peduzzi P (1993) Distribution of viruses and dissolved DNA along a coastal trophic gradient in the northern Adriatic Sea. Appl Environ Microbiol 59:4074-4082

Weinbauer MG, Fuks D, Puskaric S, Peduzzi P (1995) Diel, seasonal, and depth-related variability of viruses and dissolved DNA in the northern Adriatic sea. Microb Ecol 30: $25-41$

Weinbauer MG, Brettar I, Höfle MG (2003) Lysogeny and virusinduced mortality of bacterioplankton in surface, deep, and anoxic marine waters. Limnol Oceanogr 48:1457-1465

> Wilhelm SW, Suttle CA (1999) Viruses and nutrient cycles in the sea. BioScience 49:781-788 
Wommack KE, Colwell RR (2000) Viroplankton in aquatic ecosystems. Microbiol Mol Biol Rev 64:69-114

Wommack KE, Hill RT, Kessel M, Russek-Cohen E, Colwell RR (1992) Distribution of viruses in the Chesapeake Bay. Appl Environ Microbiol 58:2965-2970

Wu J, Chung SW, Wen LS, Liu KK, Chen YLL, Chen HY, Karl DM (2003) Dissolved inorganic phosphorus, dissolved iron, and Trichodesmium in the oligotrophic South China Sea. Global Biogeochem Cycles 17, 1008, doi: 10.1029/ 2002GB001924

Wyrtki K (1961) Physical oceanography of the Southeast Asian

Editorial responsibility: Curtis Suttle,

Vancouver, British Columbia, Canada waters. Naga Report, Vol 2, Scientific results of marine investigations of the South China Sea and the Gulf of Thailand 1959-1961. Scripps Institution of Oceanography, La Jolla, CA

> Yin K (2003) Influence of monsoons and oceanographic processes on red tides in Hong Kong waters. Mar Ecol Prog Ser 262:27-41

Yin K, Qian PY, Chen JC, Hsieh DPH, Harrison PJ (2000) Dynamics of nutrients and phytoplankton biomass in the Pearl River estuary and adjacent waters of Hong Kong during summer: preliminary evidence for phosphorus and silicon limitation. Mar Ecol Prog Ser 194:295-305

Submitted: November 20, 2007; Accepted: October 27, 2008 Proofs received from author(s): January 28, 2009 